\title{
Effect of Drug Abuse Counselling Training: Adaptation of Motivational Interviewing Strategy on Empathy, Confidence, Change Behaviour Skill and Self-Esteem among Prison Officers in Sabah
}

\author{
Puteri Hayati Megat Ahmad, Nurul Hudani Md Nawi*, Azreel Azim Abdul Alim \\ Fakulti Psikologi dan Pendidikan, Universiti Malaysia Sabah, Jalan UMS, 88400 Kota Kinabalu, Sabah \\ *Corresponding author: nurul@ums.edu.my
}

Article history: Received: 16 January 2020 Received in revised form: 20 September 2020 Accepted: 01 October 2020 Published online: 31 December 2020

\begin{abstract}
The correctional officers in Sabah Prison have not received any specific training to treat drug abusers, even though they consist the highest percentages of inmates. The Adaptation of Motivational Interviewing, AMI Treatment Modules, has been used as the training module in this project. This project aims to transfer drug abuse counselling skills to 67 prison officers in Sabah. Participants were trained for 5 days with various training methods, and the instruments used were Counseling Response Questionnaires (CRQ), Confidence and Knowledge Scale (CKS), Behavior Change Counselling Index (BECCI) and Rosenberg Self-Esteem. This study uses a quasi-experimental design aimed at seeing the effectiveness of AMI's training. Result from Wilcoxon signedranks test showed that the mean for post-test ranks was higher than the mean pre-test ranks for empathy $(z=-7.14, p<.05$, confidence $(z=-6.95, p>.05)$, change behavior skill $(z=-5.99, p>.05)$ as well as self- esteem $(z=-4.98, p>.05)$. In other words, the study showed that the Drug Abuse Counselling Training: Adaptation of Motivational Interviewing Strategy can promote positive effects on subject' empathy, confidence, change behavior skill and selfesteem. Therefore, the five-day workshop based on the AMI Treatment Modules can be used as a guideline for relevant authorities such as the Malaysia Prison Department for future training programmes particularly to correctional officers. In conclusion, this project has been able to enhance empathy, confidence and behavior-changing skills as well as self-esteem among prison officers in Sabah.
\end{abstract}

Keywords: Motivational Interviewing, drug abuse counseling training, empathy, confidence, behaviour change.

Abstrak

Pegawai penjara di Penjara Sabah tidak menerima apa-apa latihan khusus untuk merawat penyalahgunaan dadah, walaupun mereka terdiri daripad a peratusan tertinggi banduan. Adaptasi daripada Motivational Interviewing, Modul Rawatan AMI, telah digunakan sebagai modul latihan dalam projek ini. Projek ini bertujuan untuk memindahkan kemahiran kaunseling penyalahgunaan dadah kepada 150 pegawai penjara di Sabah. Peserta telah dilatih selama 5 hari dengan pelbagai kaedah latihan, dan antara instrumen yang digunakan ialah kaunseling Responden Kaunseling (CRQ), Skala Keyakinan dan Pengetahuan (CKS), Indeks Kaunseling Perubahan Bergaya (BECCI) dan Rosenberg Self-Esteem. Kajian ini menggunakan reka bentuk kuasi eksperimen yang bertujuan untuk melihat keberkesanan latihan AMI. Hasil ujian Wilcoxon sign-rank menunjukkan bahawa min untuk peringkat pasca-ujian adalah lebih tinggi daripada nilai min pra-ujian untuk empati $(\mathrm{z}=-7.14, \mathrm{p}<.05$, keyakinan $(\mathrm{z}=-6.95, \mathrm{p}>.05)$, ubah kemahiran tingkah laku $(\mathrm{z}=-5.99$, $\mathrm{p}>.05)$ serta harga diri $(z=-4.98, p>.05)$. Dalam lain perkataan, dapatan kajian menunjukkan bahawa Latihan Kaunseling Penyalahgunaan Dadah: Adaptasi Motivational Interviewing boleh menggalakkan kesan positif terhadap subjek 'empati, keyakinan, perubahan kemahiran tingkah laku dan penhargaan diri. Oleh itu, bengkel lima hari berdasarkan Modul Rawatan AMI boleh digunakan sebagai panduan kepada pihak berkuasa yang berkaitan seperti Jabatan Penjara Malaysia untuk program latihan pada masa depan khususnya kepada pegawai-pegawai penjara. Kesimpulannya, projek ini dapat meningkatkan kepekaan empati, keyakinan dan kemahiran mengubah tingkah laku serta peningkatan penhargaan diri dalam kalangan pegawai penjara di Sabah.

Kata kunci: Motivational Interviewing, latihan, empati, keyakinan, perubahan tingkah laku.

(C) 2021 Penerbit UTM Press. All rights reserved

\subsection{INTRODUCTION}

The Motivational Interviewing, MI is a client-centered, directive therapeutic method designed to enhance motivation for change by helping individuals to explore and resolve ambivalence (Hettema, 2006). It is an evolution of person-centered therapy which elicits the client's own motivation for change (Hettema, Steele \& Miller, 2005). MI is a highly clinical counselling approach that requires therapists to master the core skills OARS (O-Open Question, A-Affirming, R-Reflecting, and S-Summarizing).

The Adaptation of Motivational Interviewing, AMI, is a prototype of MI. These two strategies are common in orientation of communication style, spirit, principles, goals, and the assumption of the ability to produce voluntary clients' changes of behaviour. The AMI strategy is fit and often aligns with Transtheoretical Model (TTM) of Change, which was introduced by Prochaska and Norcross 
(2004). AMI in this study refers to drug abuse counselling, therapeutic humanistic approach, emphasizing the mastery of OARS skills, and the use of AMI. This AMI training was given to semi-professional individuals who were involved in the treatment of drug abuse in Sabah prisons. It also refers to the module of the counselling aid practice of drug abuse with 10 sessions being implemented as a part of the practice elements which will be implemented on the respondents. This module combines the MI skills with the non-MI skills, apart from the presence of elements such as feedback from the individuals who are not professional to aid the change in attitude or behaviour.

AMI, just as MI, is a counselling strategy that is always related to addict nursing or known as the main intervention to nurse substance abuse (Hettema et al., 2005). It is a nursing initiative with the most empirical evidence in the aspect of nursing effectiveness apart from Cognitive Behavioural Skill Practice (Latihan Kemahiran Tingkah Laku Kognitif), (Burke, Arkowitz \& Dunn, 2002; Dunn, DeRoo \& Rivara, 2001). AMI is also proved as a means with effective cost initiative (project MATCH Research Group, 1997).

AMI is a popular and dominant strategy related to drug addiction treatment or known as the main intervention to treat substance abuse (Hettema et al., 2005). It is a treatment approach with the most empirical evidence in its' effectiveness apart from Cognitive Behavioural Therapy, (Burke et al., 2002; Dunn et al., 2001). AMI has also been proven as a cost-effective strategy in substance abuse treatment (project MATCH Research Group, 1997).

Recovery officers at Sabah Prison institutions did not receive special training to treat drug offenders, even though the highest percentage of the imprisonments were related to drug abuse. According to 2014 statistics, offenders at Sabah Prison institutions are around 4000 to 5000, and 70 percent of them are involved with drug abuse cases. In addition, the highest recidivist rate statistics are al so comprised from these groups.

The rehabilitation program carried out at Sabah prison at the time was far too general and there had been no specific treatment to treat prisoners of drug abuse. Hence, special training for prison recovery officers should be implemented so that all prison recovery officers have the required skills and can effectively treat the prisoners. Instead of Therapeutic Community (TC) Programme, the prison recovery personnel need to be exposed to other alternative strategies so that they can tailor their treatment based on their clients' needs. The treated prisoners hope to fully recover, so that they are able to live a meaningful life and contribute to society.

\subsection{LITERATURE REVIEW}

The need The drug abuse counselling strategy of AMI is a humanistic strategy and is capable of reducing resistance from the client. Therefore, the suitable theory used in the current study is Person Centered Therapy. This theory places great emphasis on the individual's ability to move in positive directions. It was called as humanistic approach to communication that initially arose as an alternative to confronta-tional, directive treatments for substance use. In addition to incorporating a series of techniques, MI represents a way of being'with clients (Miller and Rollnick, 2013). The spirit of MI is based upon four vital components: partnership, acceptance, compassion and evocation.

Practitioners of the theory have a belief in the trustworthiness of individuals and in their innate ability to move toward selfactualization and health when the proper conditions are in place. Tied to these beliefs is the confidence that individuals also have the inner resources to move themselves in such positive directions. Besides, this strategy can be learned and easily acquired, as it can fit precisely with any kind of values, norms and cultures. In addition to that, AMI training will specifically enhance the skills and confidence of respondents (prison recovery officers) in implementing a treatment method which could help drug abuse clients to change their behavior.

Besides, research done by Puteri Hayati, Shuaib Che Din, and Chua Bee Seok in 2013 on the effectiveness of AMI Training in Malaysia using a quasi-experimental method involve of 113 trainee counsellors. The findings show significant differences before and after skills-related training (empathy response, confidence in counselling, MI skills) of the treatment group which shows that training can enhance counselling skills among trainee counsellors. This study contributes to the strengthening of AMI's position as a therapeutic method and in terms of utilitarian value; the resulting training manual has become one of AMI's treatment model of drug abuse counselling in Malaysia.

A study done by Miller and Mount (2001) to evaluate the effectiveness of AMI's workshops (15 hours) involved 24 parole officers and community recovery officers as subjects through didactic teaching, demonstration and small-group practices. Through this study, knowledge, proficiency, and use of AMI techniques increased and a decrease in MI's inconsistent response after training. This highlighted that AMI training was able to bring impact on knowledge, competencies, and confidence level of the respondents, and these skills can be sustained for four months follow-up. Similarly, the increased use of reflection response and MI's consistent skills, as well as the high ratio of trainees' competence in knowledge, AMI techniques, empathy responses, reflection responses, MI's consistent skills, and overall MI skills (acceptance, egalitarian and empathy). Training studies to date shows a large effect of MI training on helpers' proficiency index, particularly when initial training is accompanied by learning aids such as personal feedback and coaching (Catley et al., 2006; Schoener, Madeja, Henderson, Ondersma, \& Janisse, 2006; Thrasher et al., 2006; Welch, Rose, \& Ernst, 2006)

Based on the previous research, it was found that training can enhances skills and proficiency of MI. AMI training is equally important as it can provide alternatives to prison officers especially in Sabah regarding the treatment methods that can be used. Under the Knowledge Transfer Programme, 150 Sabah prison officers were trained in 2016-2017 with the allocation of RM104,140.00 by Kementerian Pengajian Tinggi. The Treatment Module consisting of 10 sessions of AMI was used as part of these training elements.

This study aims to identify the effectiveness of the AMI training and the differences of participants' score related to empathy response, confidence, change behavior skills and self-esteem. Therefore, the research hypotheses were created based on the research theoretical framework and past studies. 
Hypothesis1: There is a significant effect of empathy response towards Drug Abuse Counselling Training: Adaptation of Motivational Interviewing of between pre and post-studies.

Hypothesis2: There is a significant effect of confidence towards Drug Abuse Counselling Training: Adaptation of Motivational Interviewing of between pre and post-studies.

Hypothesis3: There is a significant effect of behavior-changing towards Drug Abuse Counselling Training: Adaptation of Motivational Interviewing of pre and post-studies.

Hypothesis4: There is a significant effect of self-esteem towards Drug Abuse Counselling Training: Adaptation of Motivational Interviewing between pre and post-studies.

\section{Research Framework}

Theoretical framework is a framework of general principles or basic principles that form the basis for the formation or development of a knowledge. According to Ary, Jacobs and Razavieh (1996), the theoretical framework in a study is aimed at determining the question of the study to be done. It is a guide to determine the orientation of the investigation to be performed. In this sense, the the oretical framework was presented that start with the pretest then was followed by giving treatment knows as training. Lastly the subjects at last examined the posttest (Refer Figure 1). As for the dependent variable here refers to training of Motivational Interviewing Adaptation (AMI) and independent are confidence, empathy, change behavior and self -esteem.

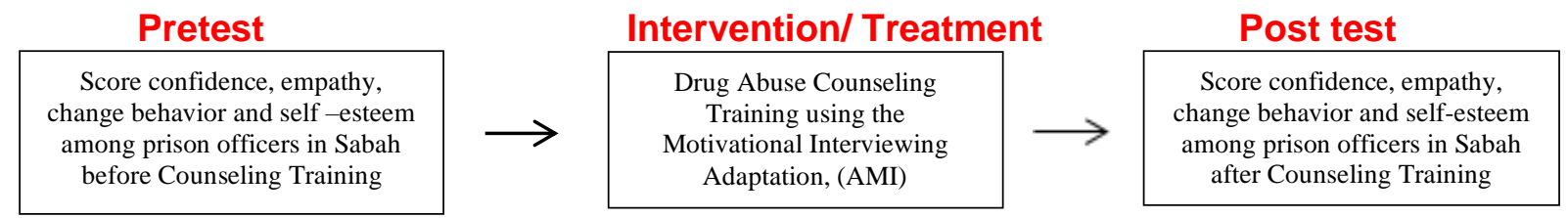

Figure 1: Study framework - Drug abuse counseling training using Motivational Interviewing (AMI) Adaptation to improve empathy, confidence, behavior change and self-esteem among prison officers in Sabah.

Based on the above diagram it can be concluded that the results of this study are from various aspects especially from the type of knowledge that will be transferred ie when all participants (prison rehabilitation officers) can increase the level of mastering basic counseling skills (doing restructuring, building relationships, conducting counseling process, and understand the drug client's body language). Additionally, increased knowledge and understanding of the concept of effective drug abuse counseling (from humanistic approach to humanistic) and the enhancement of Motivational Interviewing (AMI) Adaptation strategy skills such as behavior change behavior. Additionally, enhancement of OARS Early Learning (Open Question, Affirmation, Reflection, Summarizing) skills and skills to identify client stages of change and conversational conversions.

The next contribution is that in applying the individual counseling of four structured drug abuse sessions by using the module provided it will enhance the understanding and knowledge of drug pharmacology. All participants will also master the basic skills of counseling (doing the right structuring, building relationships, conducting counseling process accurately, mastering skills and understanding the client's language of drug abuse).

In addition, all participants can show non-conforming and humanistic responses. Additionally, all participants are able to conduct treatment towards changing the client's unprofitable behavior and will master the initial method of Motivational Interviewing (AMI) OARS (ie open-ended questions, reinforcing, reflection responses and formulas).

\subsection{METHODOLOGY}

\section{Research Design}

This study uses a quasi-experimental design aimed at seeing the effectiveness of AMI's training. Before the study began, ethical approval was first obtained from the Prison Office and Ethics Committee, Malaysia. Upon this official clearance, initial verbal contact was then made to the selected prison authorities to explain the intention of the study, the period involved and what was required from the prison staff. This process was later followed by an official letter of application plus the approval from the selected prison. Upon receiving the official approval from each prison, a further verbal discussion through the telephone was made to the prison director or the appointed coordinator(s). The aim was to arrange the date and time of the day(s) suitable for meeting the subjects. Therefore, respondents' selection was carried out by Sabah Prison. On the agreed meeting day, the researchers and assistants met, explained and invited potential patients to participate in the study In this study, each participant responded to a set of questionnaire which consists of several parts, i.e., demographic profile and scale on empathy responses, confidence, behavior-changing skills and self-esteem. In order to reduce bias, will make sure that each and every participant has not involved in any AMI training before and assume that their knowledge and skill limited and do not expose to humanistic approach. 


\section{Participants}

Respondents of the study consisted of 80 prison officers from Sabah and the respondents' selection was carried out by Sabah Prison. However, only 67 respondents only were used in data analysis based on complete y provided by respondents.

\section{Procedure}

To transfer the specific skills of OARS (Open Question, Affirmation, Reflection, and Summarizing) and behavior-changing skills, a fiveday training was conducted in six series. Various method of learning such as lectures - is an oral presentation intended to present information or teach subject about AMI, demonstrations - give a practical exhibition and explanation by trainers, role plays - perform the part of a person or character, for example as a technique in AMI training, simulations - model or representative example of AMI training, session recording analysis, and the involvement of real clients (drug abuse prisoners) have been used in this training.

\section{Instruments}

A set of questionnaire used is a Malay version back translation by the previous researchers that consists of two sections distributed to participants;

Section A: Measures the demographic profile such as age, gender, religion, position, salary grade, service periods, and education.

Section B: Counselling Response Questionnaires (CRQ) (Ernst, 2007) is an instrument used to measure empathy responses (reflective statements) based on six given scenarios. The response to the scenario is rated by 5 - point Likert scale. The higher the rating, the higher the empathy response skills. Ratings on the responses were determined by guidelines provided by Miller et al., (2001).

The Confidence and Knowledge Scale by Poirier et al. (2004) is used to measure confidence in implementing counselling. The confidence is related to the ability to communicate well, the ability to assess the readiness of change, and the confidence to implement the AMI interventions. There are eight items on the 5-point Likert scale and the higher the scores, the higher the confidence and vice versa.

The Behavior Change Counselling Index, BECCI by Lane et al. (2005), contains 11 items to measure the level of skill in changing the clients' behavior. The BECCI answer format is based on the 5-point Likert scale where 0 describes "not at all" and 4 represent "a great extent".

The Rosenberg Self-Esteem Scale by Rosenberg (1965) consists of 10 items for measuring global self-esteem. Five items are reversed scored (item no. 2, 5, 6, 8, and 9). In this study, respondents rated themselves on four-point scale: 1 (strongly agree) to 4 (strongly disagree). Therefore, the range of possible score is 10 to 40 . For interpretation purpose, the lower the score, the higher the level of selfesteem.

\section{Reliability}

Based on Table 1, all the instruments have reliability value of more than 0.7 and are suitable for this study.. The reliability value of Counselling Response Questionnaires (CRQ) (pre-test is .799 and post-test is .808), Confidence and Knowledge Scale (pre-test is .879 and post-test is .863), The Behaviour Change Counselling Index, BECCI (pre-test is .789 and post-test is .939) and Rosenberg Self-Esteem (pre-test is .886 and post-test is .959)

Table 1: Reliability value of Counselling Response Questionnaires (CRQ), Confidence and Knowledge Scale, The Behaviour Change Counselling Index (BECCI) and Rosenberg Self-Esteem between Pre and Post Study

\begin{tabular}{llll}
\hline Variables & Item & Pre & Post \\
& & & \\
\hline CRQ & 8 & .799 & .808 \\
CKS & 6 & .879 & .863 \\
BECCI & 11 & .789 & .939 \\
Rosenberg Self Esteem & 10 & .886 & .959 \\
\hline
\end{tabular}

\section{Data Analysis}

The data were analysed by using IBM SPSS Statistics 24.0 (Statistical Package for Social Sciences). Statistical descriptive analysis like frequency whereas statistical inference analyses like Wilcoxon signed-ranks test were used. This test use in order to comparing two groups of data that are not normally distributed. 


\subsection{RESULTS}

\section{Descriptive Analysis}

There were 67 participants that took part in this study. The data in table 2 shows the percentage of males $(\mathrm{n}=60,89.6 \%)$ and females $(\mathrm{n}=7,10.4 \%)$ with a mean age $35.60(S D=7.55)$ among the respondents. The age category of $31-40$ years $(37.8 \%)$ is the highest percentage compared to other age categories. The Sabah Bumiputera ethnic group (58.2\%) was the highest ethnic group respondents compared with other ethnic groups and $76.1 \%$ are Muslim respondents. The Executive group (95.5\%) is the majority, which is also known as the implementers (KA19-KA40, S17-S27, U29) while the Professional and Management group (KA41-KA54, S41) was only 4.5\%. The highest percentage of service period was category 2 year up to 20 years (55.2\%) and majority of respondents had STPM level (37.3\%) (Refer Table 2).

Table 2 Demographic Profile

\begin{tabular}{|c|c|c|c|}
\hline Variables & & Frequency $(\mathrm{N}=67)$ & Percentage (\%) \\
\hline \multirow[t]{2}{*}{ Gender } & Male & 60 & 89.6 \\
\hline & Female & 7 & 10.4 \\
\hline \multirow[t]{4}{*}{ Age } & $21-30$ & 22 & 32.8 \\
\hline & $31-40$ & 25 & 37.8 \\
\hline & $41-50$ & 19 & 28.4 \\
\hline & $51-60$ & 1 & 1.5 \\
\hline \multirow[t]{3}{*}{ Ethnic } & Malay & 18 & 26.9 \\
\hline & B/putera Sabah & 39 & 58.2 \\
\hline & Others & 10 & 14.9 \\
\hline \multirow[t]{2}{*}{ Religion } & Islam & 51 & 76.1 \\
\hline & Christian & 16 & 23.9 \\
\hline Position & Professional & 3 & 4.5 \\
\hline In Prison & Supportive & 64 & 95.5 \\
\hline \multirow[t]{2}{*}{ Salary Grade } & Executive & 64 & 95.5 \\
\hline & $\mathrm{P} \& \mathrm{P}$ & 3 & 4.5 \\
\hline \multirow{4}{*}{$\begin{array}{l}\text { Serving period } \\
\text { (years) }\end{array}$} & $1-10$ & 7 & 10.4 \\
\hline & $11-20$ & 37 & 55.2 \\
\hline & $21-30$ & 12 & 17.9 \\
\hline & $31-40$ & 11 & 16.4 \\
\hline \multirow[t]{5}{*}{ Education } & SRP & 1 & 1.5 \\
\hline & SPM & 6 & 9 \\
\hline & STPM & 25 & 37.3 \\
\hline & Diploma & 22 & 32.8 \\
\hline & Degree & 13 & 19.4 \\
\hline
\end{tabular}

Table 3 The Results of the Wilcoxon Signed-ranks Test on of empathy response, confidence, and the change behavior skill between Pre and Post Study

\begin{tabular}{|c|c|c|c|c|c|}
\hline Components & Group & $N$ & Mean Rank & $\mathbf{Z}$ & Sig \\
\hline Empathy & $\begin{array}{l}\text { Pre } \\
\text { Post }\end{array}$ & 67 & $\begin{array}{l}6.45 \\
19.19\end{array}$ & -7.14 & .000 \\
\hline Confidence & $\begin{array}{l}\text { Pre } \\
\text { Post }\end{array}$ & 67 & $\begin{array}{l}25.00 \\
33.00\end{array}$ & -6.96 & .000 \\
\hline $\begin{array}{l}\text { Change Behavior } \\
\text { Skill }\end{array}$ & $\begin{array}{l}\text { Pre } \\
\text { Post }\end{array}$ & 67 & $\begin{array}{l}12.19 \\
30.44\end{array}$ & -5.99 & .000 \\
\hline Self Esteem & $\begin{array}{l}\text { Pre } \\
\text { Post }\end{array}$ & 67 & $\begin{array}{l}21.40 \\
28.22 \\
\end{array}$ & -4.98 & .000 \\
\hline
\end{tabular}

Based on Table 3, our study showed that participants' score on empathy, confidence, change behavior skill and self -esteem towards Drug Abuse Counselling Training: Adaptation of Motivational Interviewing Strategy were increased after they were involved in the five-days' workshop. A Wilcoxon signed-ranks test showed that the mean for post-test ranks for participants' empathy, confidence, change behavior skill and self -esteem towards Drug Abuse Counselling Training: Adaptation of Motivational Interviewing Strategy was higher than the mean pre-test ranks. 
The results found that four variables (i.e., empathy, confidence, change behavior skill and self-esteem showed a significant difference in the mean pre-test ranks and post-test ranks. A Wilcoxon signed-ranks test showed that the mean for post-test ranks was higher than the mean pre-test ranks for empathy $(z=-7.14, p<.05$, confidence $(\mathrm{z}=-6.95, \mathrm{p}>.05)$, change behavior skill $(\mathrm{z}=-5.99, \mathrm{p}>.05)$ as well as self- esteem $(\mathrm{z}=-4.98, \mathrm{p}>.05)$.

\subsection{DISCUSSION AND RECOMMENDATION}

Research on effectiveness adaptation of AMI is still growing, the very little research has been conducted among prison officers. However according to this study, it found that AMI was an effective strategy in helping clients in a substance abuse treatment program reach treatment goals when implemented by competent staff. In general, however, research on the use of AMI with Asian populations is extremely limited. Furthermore, the results support the using of Person Centered Therapy in this current study because it places great emphasis on the individual's ability to move in positive directions. It was called as humanistic approach to communication that initially arose as an alternative to confronta-tional, directive treatments for substance use. It applies most of Rogers' therapy attitudes and techniques such as empathy, acceptance, autonomy support, collaborative style, and confidence in the client's ability to change. Below the further detail for each objective include in this study.

\section{Empathy Response}

The findings have found a significant increase statistically for the empathy responses when compared with its pre and post training mean scores. The finding of this study is parallel with a study done by Miller et al., (2004) where the ability to listen reflectively (empathy response) increases after going through training. This shows that the AMI training has given the focus on empathy response so that respondents could give empathy responses when implementing treatment with the drug abusers. The means of training highlights on simulation where respondents were being given real life clients.

The empathy response is the ability/skill in active listening which is one of the most critical skills in the drug abuse counselling. This skill helps respondents to understand the clients' point of view and to help them feel as if they are actually being listened to and being paid attention to. The empathy response is a humanistic way not confrontational and it is able to annihilate objection which is communication trait of the drug abusive clients. Through the footage analysis of the simulation sessions, respondents could identify the response of the clients' objections; fix the weaknesses in interaction and to identify the change in clients verbally. Barak (1990) found that empathy increases after trainers involved themselves with the simulation circle because respondents obtained experience through their involvement/roles. Empathy is a universal element and it can be accepted in almost all psychotherapies and because of that, it is the element that cannot be neglected during treatment training. To help clients with their improvement verbally, respondents need to master the empathy response skill which is deemed as critical in treatment training under AMI strategy. From the perspective of diversity in cultures, counsellors who were able to show sympathy are also able to show care and envision

\section{Confidence}

The result showed that there is a statistically significant increase in rrespondents' confidence when compared to the pre and post training mean scores. The effectiveness of AMI training managed to increase confidence which is the proficiency of respondents implementing the treatment. It is also supported by Rubak (2006) where Rubak mentioned that the change in the level of therapists' proficiency can be evaluated through their confidence in using AMI as a strategy in their treatments.

The increase in confidence after attending such training was also supported by the findings of Goggin et al. (2010). These findings relate to the various training methods such as demonstration and play role with real clients. The role play method requires the respondent to re-perform the skill activities taught through lectures. This training format helps the respondents to increase their confidence and competence which is parallel with the findings of Lundahl and Burke (2009).

\section{The Change Behaviors Skill}

The findings showed that there is a statistically significant increase in behavior change skill when compared to the mean score before and after the training. This is in line with the study by Lane et al. (2008) which found that the change behaviours skill improved after going through MI workshops for two days. The enhancement of the skills of respondents also relates to the various topics/element of training such as Concepts and Principle of Motivational Interviewing, Counseling Basic Skills, OARS skills, Readiness of Change and Use of AMI Structured Modules which have been developed by researcher.

The findings of this study strengthen the position of AMI treatment in Sabah Prisons and generally in Malaysia as one of the treatment alternative for substance abuse client. This study also proves that AMI training that has been implemented can be an AMI training model in Malaysia, in line with the study by Puteri Hayati, Shuaib Che Din and Chua Bee Seok, (2013).

\section{Self - Esteem}

These findings showed that there is a statistically significant increase in self - esteem when compared to the mean score before and after the training. Self-esteem level was found to be higher after involved in AMI training. This could mean AMI activities led to increase in self-esteem among the participants. An increase in self-esteem is a possible self-efficacy and self-identity for the prison officers. This explanation relates well with the enhancement function of volunteering as described by Clary, Snyder, Ridge, Copeland, Stukas, Haugen, and Miene (1998). According to these authors, the enhancement function refers to the psychological benefits such as feeling good about oneself - which is very much related to self-esteem. 
This result was consistent what Rosenberg (1965) said about self-esteem. It is a positive or negative orientation towards the self. It is part of an individual's trait. It refers to the overall evaluation of one's worth. As report by Ikechukwu Uba, Siti Nor Yaacob, Mansor Abu Talib, Sakineh Mofrad, and Rohani Abdullah (2013) self - esteem is extensively documented as a vital facet of psychological work. Any stressful life were significantly reduced when a person possess high level of self- esteem. In this study, self-esteem level was found to be higher among the subjects after involved in the 5 days training. This could mean subjects either start with a lower self-esteem, or the training activities led to increase in self-esteem. People are motivated to participate in these training activities partly due to the anticipated positive effect it has. An increase in self-esteem is a possible reward for themselves. This explanation relates well with the enhancement function of human as described by Clary et al., (1998). According to these authors, the enhancement function refers to the psychological benefits such as feeling good about oneself - which is very much related to self-esteem.

Moreover, self-esteem is not only the fundamental element of all the mental problem but the scholars argued that is also protects and contribute in order to improved many health issue and confident in the everyday interaction as well as social life. This is because it will buffer negative and harmful effects.

\subsection{CONCLUSION}

The prison officers needed specific skills such as empathy, confidence and behavior-changing skills when dealing with drug abuse offenders. This AMI strategy could help the officers to treat the drug abusers effectively. Prison officers should provide a conducive atmosphere, the skill of attending behavior, ability to listen and respond accurately. Hence a comprehensive training element and the diversity in training approaches have been able to provide competencies to prison recovery officers.

Education is a way to develop the personality of helpers and due to that, the Prisons Department of Malaysia provides education through training to improve the skills of prison officers in order to help the well-being of prisoners. This is in line with the slogan 'Education for All' of The United Nations Educational, Scientific and Cultural Organization (UNESCO 2000).

This study was conducted to identify the effectiveness of training in educating officers using a humanistic approach rather than a commonly used of confrontation. Training will help prison recovery officers to understanding of AMI's strategies, acquires high level of proficiency, aware of the need of the clients, and understand the perspective of drug abuser from their point of view. This understanding will lead to awareness about the helping the prisoners of drug abuse through education and not solely by punishment.

Finally, this study has proved that the AMI training has been able to provide the differences in efficiency of Sabah Prison officers. The Adaptation of Motivational Interviewing Treatment Module (AMI), which was used as one of the elements in training has been accepted as one of the treatment modules for enhancing positive human development in Sabah prisons for drug abusers.

\section{References}

Ary, D., Jacobs, L.C. and Razavieh, A. (1996) Introduction to Research in Education. Harcourt Brace College Publishers, Fort Worth.

Barak, A. (1990). Counselor training in empathyby a game procedure. Counselor Education and Supervision. 29, 170-179

Burke, B. L., Arkowitz, H., \& Dunn, C. (2002). The efficacy of motivational interviewing and its adaptions. In W. R. Miller and S. Rollnick. Motivational Interviewing: Preparing people for change, 217 - 250. New York: Oxford University Press.

Catley, D., Harris, K. J., Mayo, M. S., Hall, S., Okuyemi, K. S., Boardman, T., \& Ahluwalia.

(2006). Adherence to principles of motivational interviewing and client within-session behavior. Behavioural \& Cognitive Psychotherapy, 34, 43-56.

Clary, E. G., Snyder, M., Ridge, R. D., Copeland, J., Stukas, A. A., Haugen, J., \& Miene, P. (1998). Understanding and assessing the motivations of volunteers: A functional approach. Journal of Personality and Social Psychology, 74(6), 1516-1530

Dunn, C., DeRoo, L., \& Rivara, F. (2001). The use of brief intervention adapted from motivational interviewing across behavioral domains: A systematic review. Addiction, 96, 1725 - 1742.

Ernst, D. (2007). Motivational Interviewing And Health Coaching: A Quantitative and qualitative exploration of integration. (Doctoral Dissertation). University of New Mexico.

Goggin, K., Hawes, S. M., Duval, E. R., Spresser, C. D., Martinez, D. A., Lynam, I., Barnes, A., Hinton-Dampf, A. M., Murphy, M. E., Marken, P. A., \& Catley, D. (2010). Instructional design and assessment: A motivational Interviewing course for Pharmacy student. American Journal of Pharmaceutical Education. 74(4), article 70 .

Hettema, J. (2006). A Meta-Analysis Of Motivational Interviewing Across Behavioural Domains. Doctoral Dissertation. University of New Mexico, Albuquerque, New Mexico.

Hettema, J., Steele, J. \& Miller, W. R. (2005). Motivational interviewing. Annual Review of Clinical Psychology, 1,91 - 111.

Ikechukwu Uba, Siti Nor Yaacob, Mansor Abu Talib, Sakineh Mofrad, and Rohani Abdullah (2013). Effect of Self-Esteem in the Relationship between Stress and Substance Abuse among Adolescents: A Mediation Outcome, International Journal of Social Science and Humanity, 3(3): $214-217$.

Lane, C., Huws-Thomas, M., Hood, K., Rollnick, S., Edwards, K., \& Robling, M. (2005). Measuring adaptation of motivational interviewing: The development and validation of Behavior Change Counselling Index. Patient Educ Couns, 56, 166 - 173.

Lane, C., Hood, K.., \& Rollnick, S. (2008). Teaching motivational interviewing: Using Role play is as effective as using simulated patients. Medical Education. 42, 637-644.

Laura Cordisco Tsai \& Ivy F. Seballos-Llena (2019): Reflections on Adapting Motivational Interviewing to the Filipino Cultural Context. Practice: Social Work In Action, 1(1), 1-15

Lundahl, B., \& Burke, B. L. (2009). The effectiveness and applicability of motivational interviewing : a practice-friendly review of our meta-analysis. Journal of Clinical psychology, 65(11), 1232-1245.

Miller, W. R., Yahne, C. E., Moyers, T. B., Martinez, J. \& Pirritano, M. (2004). A randomized trial of methods to help clinicians learn motivational interviewing. Journal of Consulting and Clinical Psychology, 72 (6), 1050-1063.

Miller, W. R., \& Mount, K. A. (2001). A small study of training in motivational interviewing: Does one workshop change clinician and client behavior? Behavioral and Cognitive Psychotherapy, 29, 457 - 471.

Miller, W. R., \& Rollnick, S. (2013). Motivational interviewing: Preparing people to change. (3nd ed.). New York: Guilford Press.

Poirier, M. K., Clark, M. M., Cerhan, J. H., Pruthi, S., Geda, Y. E., \& Dale, L. C. (2004). Teaching motivational interviewing to first-year medical students to improve counseling skills in health behavior change. Mayo Clinic Proc, 79, 327 - 331.

Prochaska, J., \& Norcross, J. (2004). System of Psychotherapy; A Transtheoritical Analysis (5th ed.). New York: Wadsworth. 
Puteri Hayati (2017). Modul rawatan adaptasi Motivational Interviewing, AMI kaunseling individu/bimbingan berstruktur sepulu h sesi. UMS: Fakulti Psikologi dan Pendidikan

Puteri Hayati Megat Ahmad, Md Shuaib Che Din \& Chua Bee Seok (2013). Kesan latihan strategi kaunseling Adaptasi Motivational Interviewing (AMI) terhadap kaunselor pelatih. Journal of Psychology and Human Development, 1(1), 22 - 28.

Project MATCH Research Group. (1997). Matching alcoholism treatments to client heterogeneity: Project MATCH post treatment drinking outcomes. Journal of Studies on Alcoholism, 58, 7 - 29.

Rubak, S. L. (2006). Motivational interviewing in intensive treatment of type 2 diabetes detected by screening in general practice. Doctoral Dissertation. University of Aarhus

Rosenberg,M. (1965).Society and the Adolescent Self-Image .New Jersey : Princeton University Press

Rosenberg, M. (1979). Conceiving the self. New York: Basic Books

Schoener, E. P., Madeja, C. L., Henderson, M. J.,Ondersma, S. J., \& Janisse, J. J. (2006). Effects of motivational interviewing training on mental health therapist behavior. Drug and Alcohol Dependence, 82, 269-275.

Thrasher, A. D., Golin, C. E., Earp, J. A. L., Tien,H., Porter, C., \& Howie, L. (2006). Motivational interviewing to support antiretroviral therapy adherence: The role of quality counseling. Patient Education and Counseling, 62, 64-71

United Nations Education, Scientific and Cultural Organization UNESCO. (2000). World Education Forum. Education for All: Global Monitoring Report. Dakar Senegal.

Welch, G., Rose, G., \& Ernst, D. (2006). Motivational interviewing and diabetes: What is it, how is it used, and does it work? Diabetes Spectrum, $19,5-11$. 